KHAZANAH MULTIDISIPLIN

VOL 2 NO 12021

https://journal.uinsgd.ac.id/index.php/kl

\title{
PERAN PASAR MODAL SYARIAH DALAM LAJU PERTUMBUHAN EKONOMI DI INDONESIA
}

\author{
Hamdan Fathoni', Gina Sakinah² \\ 1Program Studi Megister Ekonomi Islam UIN Sunan Gunung Djati \\ Bandung, Indonesia \\ ${ }^{2}$ Fakultas Ekonomi dan Bisnis Islam UIN Sunan Gunung Djati Bandung, \\ Indonesia \\ E-mail: Hamdanfathoni2014@gmail.com
}

\begin{abstract}
This study aims to examine how the role of the Sharia Capital Market as an alternative investment in accordance with Islamic sharia is associated with the economy in Indonesia nationally. This writing is processed using the literature study method obtained from various books, journals, financial statements, and other related references. Data obtained from www.ojk.go.id and www.bps.go.id show that the contribution of sharia shares is fluctuating in view of the rationalization of market capitalization, while the value of Gross Domestic Product (GDP) continues to increase every year. Judging from the Gross Domestic Product (GDP) indicator, it turns out that an increase in the number of sharia shares in each year is felt to be unable to optimally boost economic growth in Indonesia, it requires synergy of related parties so that interest in investment in the Sharia capital market is increased and can have an impact great effect on national economic growth .
\end{abstract}

Keywords: GDP, Islamic Capital Market, Growth Rate

\begin{abstract}
ABSTRAK
Studi ini bertujuan untuk mengkaji bagaimana peran Pasar Modal Syariah sebagai salah satu alternatif investasi yang sesuai dengan syariah Islam dikaitkan dengan perekonomian di Indonesia secara nasional. Penulisan ini diolah menggunakan metode studi literatur yang diperoleh dari berbagai macam buku, jurnal, laporan keuangan, serta referensi lain yang terkait. Data yang diperoleh dari www.ojk.go.id dan www.bps.go.id memperlihatkan bahwa kontribusi saham syariah bersifat fluktuatif dilihat dari rasionalisasi nilai kapitalisasi pasar, sementara nilai Produk Domestik Bruto (PDB) terus bertambah setiap tahunnya. Dilihat dari indikator Produk Domestik Bruto (PDB), ternyata peningkatan jumlah saham syariah di setiap tahunnya dirasa belum mampu mendorong laju pertumbuhan ekonomi di Indonesia secara optimal, diperlukan sinergi pihak-pihak terkait agar minat terhadap investasi di pasar modal Syariah lebih menngkat dan dapat memberi dampak besarterhadap pertumbuhan ekonomi Nasional.
\end{abstract}

Kata Kunci: PDB, Pasar Modal Syariah, Laju Pertumbuhan

\section{PENDAHULUAN}

Setiap Negara khususnya Negara berkembang senantiasa selalu berusaha meningkatkan laju pertumbuhan ekonomi sehingga mensejahterakan masyarakatnya dan berubah dari Negara berkembang menjadi Negara maju. Indonesia merupakan salah satu dari Negara 
KHAZANAH MULTIDISIPLIN

VOL 2 NO 12021

https://journal.uinsgd.ac.id/index.php/kl

berkembang dengan target peningkatan tingkat pertumbuhan ekonomi sebesar $7 \%$ sehingga dapat bersaing pada era globalisasi. Pada faktanya pencapaiaan tingkat pertumbuhan ekonomi Indonesia diarasa sangat sulit untuk meningkat. Berdasarkan data Badan Pusat Statistik (BPS), selama kurun waktu 3 tahun terahir pertumbuhan ekonomi Indonesia stagnan berada di angka $5 \%$. berikut data pertumbuhan ekonomi periode 2008 Kuartal II 2019 :

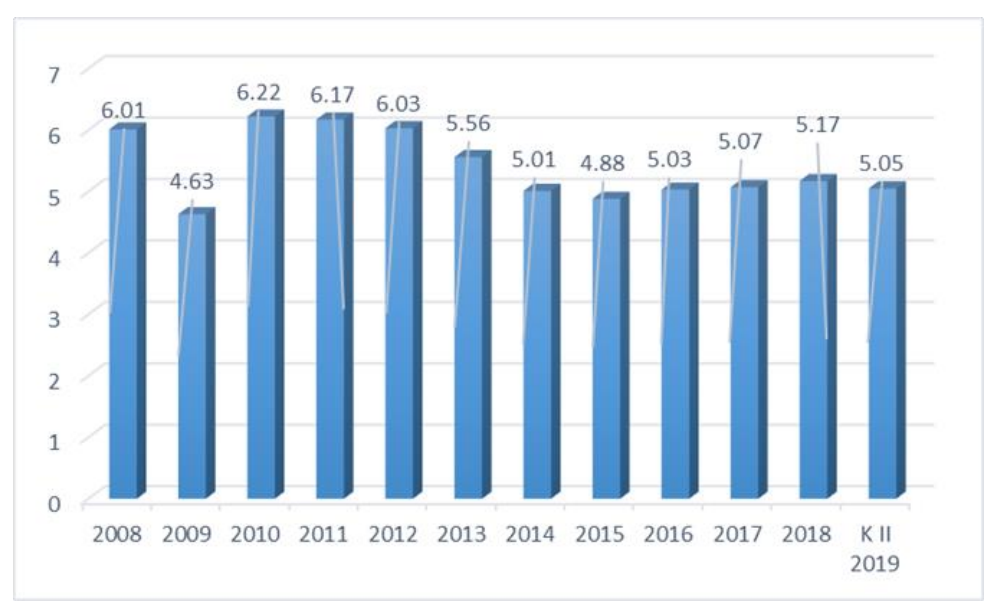

\section{Grafik 1. Presentase Pertumbuhan Ekonomi Indonesia Periode 20o8-2019 ( Sumber: www.bps.go.id )}

Pada Grafik 1 dapat dilihat Salah satu faktor peningkatan tingkat pertubuhan ekonomi adalah Terakumulasi modal, yang meliputi semua bentuk atau jenis investasi baru seperti peralatan Produksi, Aset tetap, dan peningkatan kualitas sumberdaya manusia. Dengan terakumulasinya modal tersebut dapat mempermudah dan meningkatan bagi industryindustri untuk memproduksi barang dan jasa. (Sukirno, 2010, p. 322).

Dapat diartikan semakin baik tingkat perekonomian dipengaruhi oleh Semakin tinggi nya tingkat investasi. Faktor investasi akan Bengaruh terhadap peningkatan permintaan agregat dan akan mendorong peningkatan terhadap penawaran agregat dengan Meningkatnya kapasitas produksi dari industry tersebut. Dalam perspektif yang lebih panjang stok capital dipengaruhi oleh tingkat dana yang investasiakan (Ahmad Ma'aruf \& Latri Wihastuti, 2008). 
KHAZANAH MULTIDISIPLIN

VOL 2 NO 12021

https://journal.uinsgd.ac.id/index.php/kl

Berdasarkan pemaparan tersebut, Salah satu upaya yang dilakukan Negara Indonesia untuk menyediakan faktor-faktor produksi sebagai acuan pendoronglaju pertumbuhan ekonomi adalah dengan meningkatkan sektor investasi pada instrumen pasar modal.

Pendirian Pasar modal di Indonesia dimulai sejaktahun 1912. Pada saat Itu hanya tersedia Efek dari Perusahaan-perusahaan Belanda dan pemerintah Hindia Belanda yang diperjualbelikan di pasar modal berupa saham dan obligasi. Kemudian saat perang dunia memuncak pasar modal sempat terhenti. Pada akhirnya setelah Indonesia memperoleh kemerdekaan, Pemerintah Indonesia pada tahun 1950 membuka kembali bursa efek berdasarkan diterbintaknnya UU Darurat oleh pemerintah tentang Bursa No. 13 tahun 1951 yang kemudian ditetapkan dengan UU No. 15 tahun 1952 dengan dditerbitkannya obligasi pemerintah Indonesia (Fauzan \& Suhendro, 2018).

Pasar modal adalah wahana peran aktif yang dapat dilakukan oleh masyarakat dengan menginvestasikan kekayaan pasif menjadi sector produktif dalam pembangunan perekonomian. Kemudian Investasi diartikan juga sebagai suatu kegiatan ekonomi perorangan (juridial person) sebagai upaya dalam mempertahankan dan atau meningkatkan nilai modalnya dimasa depan, baik kekayaan yang berbentuk tunai (cash money), aset bergarak, aset tidak bergerak, kekayaan intelektual, dan keahlian dibidang sumber daya Manusia. (Rokhmatussa'dyah \& Suratman, 2010, p. 3).

Seiring dengan berkembangan ekonomi serta peningkatan Kesadaran masyarakat khususnya di Indonesia dengan mayoritas penduduk muslim terhadap Kebutuhan investasi, secara tidak langsung mengharapkan adanya investasi yang berbasis syariah, sehingga diharapkan Pasar modal dalam hal ini dapat menciptakan instrument pasar modal berbasis syariah syariah dengan system Pembagian bagi hasil disesuaikan dengan kesepakatan bersama tidak berdasarkan bunga. (Nafik, 2009, p. 245) 
KHAZANAH MULTIDISIPLIN

VOL 2 NO 12021

https://journal.uinsgd.ac.id/index.php/kl

Pasar Modal Syariah di Indonesia muncul Pada 03 Juli 1997 dengan ditandai penerbitan reksadana Syariah oleh PT. Danareksa Investment Management. Kemudian resmikan oleh pemenrintah pada 14 Maret 2003 bersamaan dengan penandatanganan MoU antara DSN-MUI dan BAPEPAM-LK. (Nurul Huda \& Heykal, 2010, p. 220).

Perbedaan pasar modal berbasis syariah dengan konvensional adalah dalam penyertaan surat berharga yang merepresentasikan penyertaan modal ditempatkan pada perusahaan-perusahaan terdaftar dengan kegiatan oprasional tidak melanggar Kaidah dan prinsip syariah. Kemudian transaksi atau Akad harus dilakukan menggunakan akak-akad sesuai syariah, Akad tersebut dapat berlangsung menggunakan akad musyarakah atau mudharabah. (Soemitra, 2009, p. 138)

Sesuai dengan POJK Nomor 17/Pojk.04/2015 yang mengatur penerbitan efek syariah disebutkan bahwa Penerbitan efek berupa saham, termasuk waran syariah, harus berkedudukan emiten atau perusahan dengan kegian oprasional tidak melanggar prinsif syariah (Wiku Suryomurti, 2011, p. 129)

Menurut Otoritas Jasa Keuangan (OJK) Setiap taunnya terjadi Peningkatan pertumbuhan jumlah saham Syariah serta pastisipasi masyarakat, hal ini mengindikasikan perputaran ekonomi di pasar modal syariah yang juga meningkat yang kemungkinan akan berdampak pada ekonomi secara nasional (OJK, 2017).

Berdasakan fakta tersebut Investasi saham syariah yang dirasa sebagai salah satu alternative dalam berinvestasi ini mungkin mampu berkontribusi secara nyata dan optimal dalam pertumbuhan ekonomi secara nasional atau muncul keraguan atas kehadiran instrumen investasi saham syariah di Indonesia. Berdasarkan pemaparan tersebut, maka perlu adanya kajian yang lebih mendalam tentang peran investasi saham syariah dalam petumbuhan ekonomi di Indonesia yang akan dibahas dalam studi ini. 
KHAZANAH MULTIDISIPLIN

VOL 2 NO 12021

https://journal.uinsgd.ac.id/index.php/kl

\section{METODE PENELITIAN}

Studi ini diolah menggunakan metode studi literatur. Studi literatur merupakan salah satu metode penelitian dengan mengumpulkan, membaca, serta mencatat studi kepustakaan yang terkait dengan penelitian, lalu mengolahnya sebagai dasar untuk membangun kerangka judul dengan kesatuan yang utuh.(Zed, 2008)

Sumber studi literatur ini diperoleh dari berbagai macam buku, jurnal, serta referensi lain yang dapat digunakan dan terkait dengan peran investasi saham syariah dalam laju pertumbuhan ekonomi di Indonesia

\section{HASIL DAN PEMBAHASAN}

Beberapa indikator dalam penilaian Perkembangan pasar modal syariah adalah didasarkan pada penilaian terhadapkapitalisasi saham, nilai saham yang ditransaksikan dan indeks harga saham dipasar modal. Kemudian variabel-variabel tersebut dipengaruhi oleh stabilitas politik suatu Negara kemudian kondisi kemanan dan yang paling utama adalah Perubahan stabilitas perekonomian yang akan merefleksikan tingkat kepercayaan pelaku ekonomiterhadapinvestasi.

Pertumbuhan jumlah efek syariah yang terdaftar di Daftar Efek Syariah (DES) selama sebelas tahun terakhir ini terus meningkat. Terakhir, data jumlah saham syariah yang tercatat di tahun 2018 menyentuh angka 408. Lebih jelasnya, perkembangan jumlah saham syariah yang terdaftar di Daftar Efek Syariah (DES) periode 2008-2019 akan ditunjukkan oleh grafik sebagai berikut. 
KHAZANAH MULTIDISIPLIN

VOL 2 NO 12021

https://journal.uinsgd.ac.id/index.php/kl

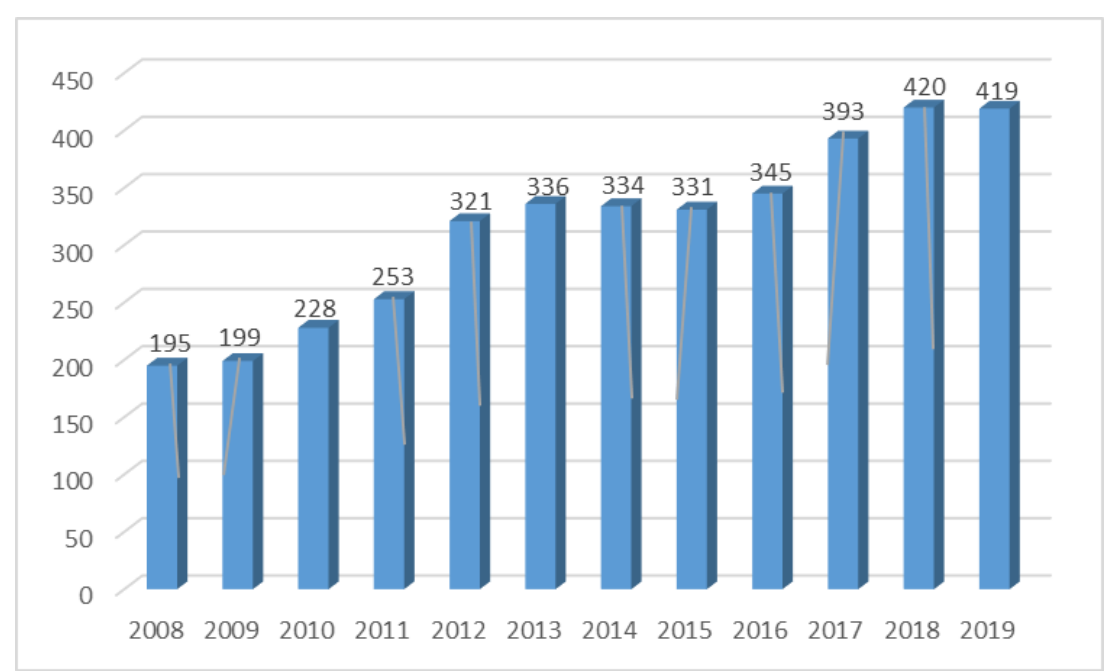

Grafik 2. Jumlah Efek Syariah yang Terdaftar di Daftar Efek Syariah (DES) Periode 2008-2019 ( Sumber: www.ojk.go.id )

Berdasarkan tabel 1 dan grafik 2 di atas, dapat terlihat bahwa jumlah saham syariah dari tahun ke tahun mengalami peningkatan yang cukup stabil. Pada tahun 2014 dan 2015 daftar efek syariah mengalami penurunan, kerna OJK melakukan penelaahaan secara periodic dan memeriksa laporan keuangan Emiten, Namun penurunan jumlah Efek ini tidak terlalu signifikan kemudian mengalami peningkatan kembali di tahun 2016, bahkan terus meningkat hingga tahun 2018 kemudian pada pertengahan tahun 2019 pada bulan Juni terjadi penurunan dan di hararapkan akhir tahun 2019 akan meningkat kembali. Berdasarkan data duatas, pertumbuhan jumlah Efek syariah dari tahun ke tahun ini mengindikasikan peningkatan perputaran ekonomi di pasar modal syariah yang juga akan berdampak pada ekonomi secara nasional.

Perkembangan investasi saham syariah tidak terlepas dari beberapa indikator yang mempengaruhinya, yaitu seperti nilai kapitalisasi pasar dan Indeks Harga Saham Gabungan (IHSG). Perkembangan investasi saham syariah yang mempengaruhi pertumbuhan ekonomi nasional ditandai dengan berpengaruhnya transaksi investasi saham terhadap indikatorindikator makroekonomi, di antaranya tingkat pertumbuhan ekonomi yang diukur berdasarkan Produk Domestik Bruto (PDB). (Fauzan \& Suhendro, 2018) 
KHAZANAH MULTIDISIPLIN

VOL 2 NO 12021

https://journal.uinsgd.ac.id/index.php/kl

Berikut disajikan tabel 1 kontribusi kapitalisasi pasar saham syariah terhadap Produk Domestik Bruto (PDB) di Indonesia periode 2008-2019.

Tabel 1. Kontribusi Kapitalisasi Pasar Saham Syariah terhadap Produk Domestik Bruto (PDB) di Indonesia Periode 2008-2018 (dalam milyar)

\begin{tabular}{|c|c|c|c|c|c|c|c|}
\hline \multirow[t]{2}{*}{ Tahun } & \multicolumn{2}{|c|}{$\begin{array}{l}\text { Kapitalisasi Pasar } \\
\text { Saham Syariah }\end{array}$} & \multirow[t]{2}{*}{$\begin{array}{l}\text { Kapitalisasi } \\
\text { Pasar IHSG }\end{array}$} & \multirow[t]{2}{*}{ PDB } & \multicolumn{2}{|c|}{$\begin{array}{c}\text { Rasionalisasi Nilai } \\
\text { Kapitalisasi Pasar } \\
\text { Saham Syariah } \\
\text { terhadap Pasar } \\
\text { Modal Indonesia } \\
\text { (\%) } \\
\end{array}$} & \multirow[t]{2}{*}{$\begin{array}{c}\text { Rasio } \\
\text { IHSG } \\
\text { terhadap } \\
\text { PDB (\%) }\end{array}$} \\
\hline & JII & ISSI & & & $\begin{array}{c}\text { JII } \\
\text { terhadap } \\
\text { IHSG }\end{array}$ & $\begin{array}{c}\text { ISSI } \\
\text { terhadap } \\
\text { IHSG }\end{array}$ & \\
\hline 2008 & $428.525,74$ & - & $1.076 .490,53$ & $4.948 .688,30$ & 39,81 & - & 21,75 \\
\hline 2009 & $937.919,08$ & - & $2.019 .375,13$ & 5.606 .203 & 46,45 & - & 36,02 \\
\hline 2010 & $1.134 .632,00$ & - & $3.247 .096,78$ & 6.864 .133 & 34,94 & - & 47,30 \\
\hline 2011 & $1.414 .983,81$ & $1.968 .091,37$ & $3.537 .294,21$ & $7.831 .726,00$ & 40,00 & 55,64 & 45,17 \\
\hline 2012 & $1.671 .004,23$ & $2.451 .334,37$ & $4.126 .994,93$ & $8.615 .704,50$ & 40,49 & 59,40 & 47,90 \\
\hline 2013 & $1.672 .099,91$ & $2.557 .846,77$ & $4.219 .020,24$ & $9.546 .134,00$ & 39,63 & 60,63 & 44,20 \\
\hline 2014 & $1.944 .531,70$ & $2.946 .892,79$ & $5.228 .043,48$ & $10.569 .705,30$ & 37,19 & 56,37 & 49,46 \\
\hline 2015 & $1.737 .290,98$ & $2.600 .850,72$ & $4.872 .701,65$ & $11.526 .332,80$ & 35,65 & 53,38 & 42,27 \\
\hline 2016 & $2.035 .189,92$ & $3.170 .056,08$ & $5.753 .612,75$ & $12.401 .728,50$ & 35,37 & 55,10 & 46,39 \\
\hline 2017 & $2.288 .015,67$ & $3.704 .543,09$ & 7.052 .390 & $13 \cdot 587.212,60$ & 32,44 & 52,53 & 51,90 \\
\hline 2018 & $2.239 .507,78$ & $3.666 .688,31$ & 7.023 .500 & $14.837 \cdot 357,50$ & 31,89 & 52,21 & 47,34 \\
\hline $\begin{array}{c}\text { Maret } \\
2019 \\
\end{array}$ & $2.302 .445,17$ & $3.798 .988,16$ & 7.269 .250 & $3 \cdot 782.363,40$ & 29,30 & 51,46 & - \\
\hline
\end{tabular}

Sumber : (IDX, 2020),

Berdasarkan data yang telah disajikan, indeks saham syariah di Indonesia terus berkembang dimulai dari tahun 2008 seiring dengan berkembangnya pula nilai kapitalisasi pasar saham syariah. Nilai kapitalisasi pasar memberikan gambaran nilai pasar suatu perusahaan sekaligus merefleksikan nilai pasar suatu bursa saham. Secara sederhana, dapat disimpulkan bahwa semakin besar nilai kapitalisasi pasar, maka hal tersebut menunjukkan semakin banyak pula jumlah investor yang berinvestasi di saham syariah.

Artinya Jika nilai kapitalisasi pasar saham turun maka penilaian terhadap harga saham pun turun. Nilai kapitalisasi saham dihitung berdasarkan jumlah saham dari suatu perusahaan yang tercatat dikalikan dengan harga saham masing-masing yang dibukukan di pasar. Kapitalisasi pasar suatu bursa saham memiliki korelasi secara langsung dengan Indeks Harga Saham Gabungan (IHSG). Ketika harga saham naik dan nilai 
KHAZANAH MULTIDISIPLIN

VOL 2 NO 12021

https://journal.uinsgd.ac.id/index.php/kl

pasarnya meningkat, maka akan berakibat pada kenaikan nilai Indeks Harga Saham Gabungan (IHSG). Indeks Harga Saham Gabungan (IHSG) merupakan indikator untuk mengukur tingkat keuntungan investasi serta tolak ukur dalam menilai perkembangan portofolio investasi.(Okefinance, 2017)

Berdasarkan uraian di atas, data kapitalisasi pasar saham syariah, baik Jakarta Islamic Index (JII) maupun Indeks Saham Syariah Indonesia (ISSI), telah menunjukkan keselarasan dengan nilai Indeks Harga Saham Gabungan (IHSG) selama periode 2008-2019. Penguatan nilai Indeks Harga Saham Gabungan (IHSG) ini tentunya akan berdampak pada meningkatnya pula arus investasi yang masuk ke pasar modal, tak terkecuali dari kemungkinan adanya peningkatan arus modal asing yang masuk ke Indonesia (capital inflow). Pada akhirnya, hal tersebut diharapkan akan mendorong stabilitas rupiah yang akan mendorong pertumbuhan ekonomi.(Setiawan, 2017)

Pertumbuhan ekonomi secara sederhana dapat diukur dengan melihat nilai Produk Domestik Bruto (PDB). Tingkat Produk Domestik Bruto (PDB) terus meningkat selama sebelas tahun terakhir, begitu pula dengan kapitalisasi pasar saham syariah yang hanya mengalami penurunan di tahun 2015 dan 2018, namun sisanya cukup stabil. Dapat diuraikan jika sebenarnya hubungan antara kapitalisasi pasar saham syariah dengan Produk Domestik Bruto (PDB) ini bernilai positif, namun dirasa belum sepenuhnya optimal.

Hal tersebut diperkuat dari rasionalisasi nilai kapitalisasi pasar saham syariah terhadap pasar modal Indonesia dengan indikator Indeks Harga Saham Gabungan (IHSG) yang bersifat fluktuatif. Bahkan, dari tahun 2012 hingga 2018 rasionalisasi nilai Jakarta Islamic Index (JII) terhadap Indeks Harga Saham Gabungan (IHSG) terus menurun. Meski begitu, rasionalisasi nilai Indeks Saham Syariah Indonesia (ISSI) terhadap Indeks Harga Saham Gabungan (IHSG) dinilai cukup baik karena selalu berada di atas 50\% walaupun sama-sama bersifat fluktuatif. 
KHAZANAH MULTIDISIPLIN

VOL 2 NO 12021

https://journal.uinsgd.ac.id/index.php/kl

Selanjutnya, rasio nilai kapitalisasi pasar modal Indonesia terhadap Produk Domestik Bruto (PDB) juga bersifat fluktuatif, senada dengan rasionalisasi nilai kapitalisasi pasar saham syariah terhadap Indeks Harga Saham Gabungan (IHSG). Hal ini memperkuat dugaan jika peran pasar saham syariah dalam kaitannya dengan laju pertumbuhan ekonomi masih belum dirasa optimal.

Perkembangan laju pertumbuhan ekonomi sebenarnya tidak terlepas dari peran investasi saham syariah di dalamnya. Hal ini dikarenakan perusahaan publik yang tercatat di indeks saham Jakarta Islamic Index (JII) maupun Indeks Saham Syariah (ISSI) merupakan perusahaan besar yang tentunya segala kegiatan usahanya akan berdampak pada perputaran ekonomi secara nasional hingga mempengaruhi tingkat pendapatan domestik. Namun kembali lagi, bahwa ternyata investasi saham syariah di Indonesia belum mengambil peran cukup besar dalam tingkat Produk Domestik Bruto (PDB).

Dari penjelasan yang telah dipaparkan, dapat dikatakan peran investasi saham syariah terhadap laju pertumbuhan ekonomi ini belum mencapai titik yang optimal, meski jumlah saham syariah terus meningkat di setiap tahunnya. Hal ini memperkuat penilaian bahwa tak hanya pasar saham, namun bahkan pasar modal syariah di Indonesia dinilai minim dukungan investor (Aldin, 2018). Publik ternyata masih memiliki cara pandang konvensional terhadap pasar modal syariah, sehingga hingga saat ini pasar modal syariah bukan menjadi prioritas utama saat investor akan menanamkan dananya di pasar modal.

Hambatan dalam peningkatan pasar modal syariah Pertama, kurangnya pemahaman atau Literasi oleh para investor dan masyarakat luas adalah tentang penilaian bahwa saham syariah mempunyai daya tahan lebih kuat terhadap guncangan ekonomi. Pasar saham syariah dinilai minim risiko dalam menghadapi ketidakstabilan perekonomian domestik maupun global. Hal ini dikarenakan dalam pasar saham syariah tidak terdaftar saham-saham yang mempunyai usaha dengan sistem bunga yang 
KHAZANAH MULTIDISIPLIN

VOL 2 NO 12021

https://journal.uinsgd.ac.id/index.php/kl

dianggap sebagai riba, salah satunya adalah perbankan konvensional. Sektor saham perbankan bahkan memiliki porsi yang besar di Indeks Harga Saham Gabungan (IHSG), yaitu sekitar 25\%.(Detikfinance, 2017)

Peningkatan pangsa saham syariah harus terus gencar diusahakan oleh pihak-pihak terkait, seperti kebijakan pemerintahyan yang mendukung, sinerginya kerjasama Otoritas Jasa Keuangan (OJK) dan Bursa Efek Inonesia (BEI). Keumdian sinerginya para Praktisi dan akademisi dimana Praktisi dapat mensosialisasikan keberadaan pasar modal secara pragmatis kemudian akademisi bisa mengedukasi masyarakat mengenai pasar modal syariah dalam kajian ilmiah. Strategi dapat berupa penyelenggaraan sosialisai melalui workshop, pelatiahan serta memanfaatkan fasilitas teknologi digital yang ada. Dengan gencarnya diadakan sosialisasi dan edukasi tersebut, selanjutnya diharapkan terjadi peningkatan jumlah investor yang berinvestasi di pasar modal syariah, sehingga mampu berdampak signifikan pada pertumbuhan ekonomi di Indonesia.

\section{SIMPULAN}

Perkembangan laju pertumbuhan ekonomi sebenarnya tidak terlepas dari peran investasi saham syariah di dalamnya. Pertumbuhan ekonomi secara sederhana dapat diukur dengan melihat nilai Produk Domestik Bruto (PDB). Tingkat Produk Domestik Bruto (PDB) terus meningkat selama sebelas tahun terakhir, begitu pula dengan kapitalisasi pasar saham syariah yang cukup stabil. Dapat disimpulkan jika sebenarnya hubungan antara kapitalisasi pasar saham syariah dengan Produk Domestik Bruto (PDB) ini bernilai positif, namun dirasa belum sepenuhnya optimal. Adanya faktor lain yang lebih dominan dirasa lebih mempengaruhi tingkat Produk Domestik Bruto (PDB).

Publik dinilai masih memiliki cara pandang konvensional terhadap pasar modal syariah, sehingga hingga saat ini pasar modal syariah bukan menjadi prioritas utama saat investor akan menanamkan dananya di pasar 
KHAZANAH MULTIDISIPLIN

VOL 2 NO 12021

https://journal.uinsgd.ac.id/index.php/kl

modal. Peningkatan pangsa saham syariah terus gencar diusahakan oleh pihak-pihak yang terkait. Dengan gencarnya diadakan sosialisasi dan edukasi yang dilakukan kepada masyarakat luas, selanjutnya diharapkan jumlah investor yang berinvestasi di pasar modal syariah terus meningkat dari tahun ke tahun sehingga mampu berdampak signifikan pada pertumbuhan ekonomi di Indonesia.

\section{DAFTAR PUSTAKA}

Ma'aruf, Ahmad \& Latri Wihastuti. (2008). Pertumbuhan Ekonomi Indonesia: Determinandan Prospeknya. Jurnal Ekonomi Dan Studi Pembangunan, 9(1), 44-45.

U, I, Aldin,. (2018). Jarang Dilirik Investor, Jumlah Saham Syariah Hanya Naik 7,1\%. https://katadata.co.id/berita/2018/12/05/jarangdilirik-investor-jumlah-saham-syariah-hanya-naik-71

Detikfinance. (2017). Saham Syariah Tahan Guncangan Ekonomi. dalam https://finance.detik.com/bursa-dan-valas/d-2402544/sahamsyariah-tahan-guncangan-ekonomi.

Fauzan, M., \& Suhendro, D. (2018). Peran Pasar Modal Syariah Dalam Mendorong Laju Pertumbuhan Ekonomi Di Indonesia. Prosiding SENDI_U. https://www.unisbank.ac.id/ojs/index.php/sendi_u /article/view/6030/1896, 521-533,

IDX. (2020). Indeks Saham Syariah. https://www.idx.co.id/idxsyariah/indeks-saham-syariah/

M. Nafik. (2009). Bursa Efek dan Investasi Syariah. Jakarta: PT Serambi Ilmu Semesta.

Huda Nurul, \& Heykal, M. (2010). Lembaga Keuangan Islam Tinjauan Teoretis dan Praktis. Jakarta: Kencana.

OJK. (2017). Nomor 17/Pojk.04/2015 Tentang Penerbitan Dan Persyaratan Efek Syariah Berupa Saham Oleh Emiten Syariah Atau Perusahaan Publik Syariah Bab 1 Pasal 1 Ayat 3.

A Rokhmatussa'dyah \& Suratman. (2010). Hukum Investasi \& Pasar Modal. Jakarta: Sinar Grafika.

R. Setiawan. (2017). IHSG Terus Melaju, Apa Dampaknya? https: //ekonomi.kompas.com/read/2017/11/o7/144721326/ihsg-terusmelaju-apa-dampaknya,

Soemitra. (2009). Bank dan Lembaga Keuangan Syariah. Jakarta: Kencana.

Sukirno. (2010). Makroekonomi Modern. Jakarta: PT. Raja Grafindo 


\section{KHAZANAH MULTIDISIPLIN}

VOL 2 NO 12021

https://journal.uinsgd.ac.id/index.php/kl

Persada.

Suryomurti Wiku. (2011). Super Cerdas Investasi Syariah. Jakarta: QultumMedia.

Zed, M. (2008). Metode Penelitian Kepustakaan. Jakarta: Yayasan Obor Indonesia. 